\title{
Role of antral follicle development and cumulus cells on in vitro fertilization of mouse oocytes
}

\author{
S. Cecconi, R. D'Aurizio and R. Colonna \\ Dipartimento di Scienze e Tecnologie Biomediche, 67100 L'Aquila, Italy
}

\begin{abstract}
The role exerted by antral follicle development and by companion granulosa cells on the ability of mouse oocytes at metaphase II to fuse with spermatozoa (as estimated by the kinetics of sperm-egg fusion), and to support normal fertilization (estimated by the formation of a male pronucleus) was investigated. After $17 \mathrm{~h}$ of culture in vitro, nuclear maturation occurred in $82 \%$ of oocytes derived from early antral follicles devoid of granulosa cells (denuded oocytes) and in $95 \%$ of oocytes derived from preovulatory follicles and cultured cumulus-intact or cumulus-free. Among the matured oocytes, $95 \%$ of cumulus-intact oocytes were arrested at metaphase II, while $61 \%$ of denuded and $50 \%$ of cumulus-free oocytes were arrested at metaphase I. The competence of denuded and cumulus-free oocytes to override the metaphase I stage was not affected by the addition of preantral granulosa, early antral granulosa or cumulus cells to the maturation medium. The kinetics of sperm-oocyte fusion were comparable in cumulus-intact and cumulus-free oocytes, and were more rapid than those of the early antral oocytes for insemination periods up to $60 \mathrm{~min}$. However, when denuded oocytes were matured in medium containing early antral granulosa or cumulus cells, the kinetics of sperm-egg fusion was greatly accelerated to values equivalent to those of preovulatory oocytes. The ability of denuded oocytes to fuse with spermatozoa was unaffected by the addition of preantral granulosa cells to the maturation medium. Sixty minutes after insemination, the fertilization rates were $39 \%$ for denuded oocytes, $50 \%$ for cumulus-free oocytes and $73 \%$ for cumulus-intact oocytes. The fertilization rate of denuded and cumulus-free oocytes was significantly improved by the addition to the maturation medium of cumulus cells, but not by the addition of preantral or early antral granulosa cells. Taken together, the present results show that in mice, the maturation of both oolemma and ooplasm, required for successful fertilization, is acquired together with the development of antral follicles and is positively affected by cumulus cells during meiotic progression.
\end{abstract}

\section{Introduction}

The role played by cumulus cells on the fertilizability of mammalian oocytes has been extensively studied by comparing the fertilization and embryonic development of preovulatory oocytes matured in vitro with or without cumulus cells. As reported for sheep (Staigmiller and Moor, 1984), cows (Leibfried-Rutledge et al, 1987), pigs (Mattioli et al., 1988a, b) and rats (Vanderhyden and Armstrong, 1989), only oocytes connected to cumulus cells throughout meiotic progression could be fertilized in vitro with a frequency comparable to oocytes matured in vivo. In these species, the low fertilization rate associated with cumulus-free oocytes has been frequently related to developmental abnormalities, such as delayed or absent male pronucleus formation (Niwa et al., 1976; Thibault, 1977; Leibfried and Bavister, 1983; Leibfried-Rutledge et al., 1987) or, when pronucleus development has occurred, to a considerable reduction in embryonic development (Niwa et al.,

Received 26 February 1996.
1976; Moor and Trounson, 1977; Thibault, 1977; Shalgi et al., 1979; Leibfried and Bavister, 1983; Leibfried-Rutledge et al., 1987; Vanderhyden and Armstrong, 1989). In mice, even when cumulus-free oocytes matured in vitro exhibited low fertilization rates, their capacity for embryonic development was similar to that of oocytes matured within the cumulus mass (Schroeder and Eppig, 1984). On the basis of these results, the contribution of cumulus cells to improve oocyte fertilizability has been related to the ability of cumulus cells to maintain the penetrability of the zona pellucida, rather than to affect oocyte development positively. However, since the capacity of cumulus-free oocytes matured in vitro to support formation of the male pronucleus was not investigated, it is possible that the low fertilization rates exhibited by these oocytes are due to deficient cytoplasmic maturation.

The aim of the present study was to assess the ability of the plasma membrane to fuse and pronuclei formation in preovulatory mouse oocytes matured without cumulus cells, or in the presence of soluble factors released by granulosa cells at different developmental stages. Similar experimental 
approaches were also applied to oocytes derived from early antral follicles, to evaluate the influence of antral follicle development on the acquisition by oocytes of the ability to fuse with spermatozoa and to support formation of the male pronucleus. The results demonstrate that the differentiation of oolemma and ooplasm is positively influenced by antral follicle development and by cumulus cells during in vitro maturation. The positive effect exerted by cumulus cells on oocyte fertilizability is probably mediated by factors generated within the somatic compartment and released either into the extracellular environment or directly into the oocytes through gap junctions.

\section{Materials and Methods}

\section{Animals}

Swiss CDI mice were purchased from Charles River Italia. Juvenile (10- to 12-day-old) female mice were used as donors of preantral granulosa cells. The different classes of antral oocyte were obtained from the ovaries of 23-day-old female mice that had received (primed) or had not received (unprimed) an injection of 5 iu pregnant mares' serum gonadotrophin (PMSG) $48 \mathrm{~h}$ before mating. Adult (90- to 120 -day-old) male mice were used as the source of spermatozoa.

\section{Chemicals}

All the reagents for culture media preparation were obtained from Sigma (St Louis, MO) unless stated otherwise. Pregnant mares' serum gonadotrophin was obtained from Intervet Laboratories (Oss, The Netherlands).

\section{Oocyte maturation in vitro}

Isolation of oocytes and washing procedures were performed in Hepes-buffered medium N16 (Whittingham, 1971). For maturation of oocytes, Waymouth MB 752/1 medium supplemented with $0.23 \mathrm{mmol}$ pyruvate $\mathrm{l}^{-1}, 50 \mathrm{mg}$ streptomycin sulphate $1^{-1}, 75 \mathrm{mg}$ penicillin $G$ potassium salt $\mathrm{I}^{-1}$ and $3 \mathrm{mg} \mathrm{BSA} \mathrm{ml} \mathrm{m}^{-1}$ (Way-pyr; Van de Sandt et al., 1990) was used. Preovulatory oocytes were isolated as cumulus-intact from primed animals by puncturing the largest Graafian follicles (follicle diameter larger than $400 \mu \mathrm{m}$, stage 8; Pedersen and Peters, 1968; Curci et al., 1991). Some of these oocytes were stripped of their cumulus cells by repeated pipetting (cumulusfree oocytes). By puncturing the early antral follicles (follicle diameter ranging from 200 to $300 \mu \mathrm{m}$, stage 7 , Pedersen and Peters, 1968; stage 7a, Curci et al., 1991) of unprimed mice, a large number of fully grown oocytes devoid of adherent granulosa cells (denuded oocytes) was obtained. After isolation, oocytes were cultured for $17 \mathrm{~h}$ in $5 \% \mathrm{CO}_{2}$ in air at $37^{\circ} \mathrm{C}$ in Way-pyr, and at the end of this maturation period, the cumulus-intact oocytes were completely freed of surrounding cumulus cells.

\section{Oocyte maturation in the presence of different types of granulosa cell}

All classes of granulosa cell were cultured in 96-well tissue culture plates in a final volume of $80 \mu \mathrm{l}$ Way-pyr at $37^{\circ} \mathrm{C}, 5 \%$
$\mathrm{CO}_{2}$ in air. Preantral granulosa cells were obtained by briefly incubating follicles, derived from 10- to 12-day-old mice in $0.005 \%(\mathrm{w} / \mathrm{v})$ collagenase (type XI) and $0.25 \%(\mathrm{w} / \mathrm{v})$ trypsin. The released preantral granulosa cells were washed, recovered by centrifugation $(250 \mathrm{~g}$ for $10 \mathrm{~min}$ ) and plated at a final concentration of $6 \times 10^{6} \mathrm{ml}^{-1}$. Early antral granulosa cells were released into the medium by puncturing the same follicles used to obtain denuded oocytes, and were plated at a final concentration of $6 \times 10^{6} \mathrm{ml}^{-1}$. In another set of experiments, early antral granulosa cells were treated as described above for preantral granulosa cells, and plated at a final concentration of $6 \times 10^{6} \mathrm{ml}^{-1}$. Cultures of cumulus cells were prepared by stripping away cumulus cells from about 300 cumulus-intact oocytes, and then plating the cells at a final concentration of $3 \times 10^{6} \mathrm{ml}^{-1}$.

After seeding, the three different classes of granulosa cell were covered with a Cell Culture Insert Cyclopore Membrane (0.45 $\mu \mathrm{m}$ pore size, \#3095 Falcon Plastics, Becton Dickinson Labware, Milan) adapted to microwell diameter, and denuded, cumulus-free or cumulus-intact oocytes at the germinal vesiclestage were placed on top and matured for $17 \mathrm{~h}$.

\section{Assessment of oocyte maturation}

At the end of the maturation period, all the oocytes cultured under the different experimental conditions were carefully analysed using a Wild M5A stereomicroscope to identify and separate the oocytes that had reached metaphase II, as evidenced by the presence of a polar body. The oocytes not extruding a polar body were fixed in $3.7 \%(\mathrm{w} / \mathrm{v})$ paraformaldehyde, stained with $5 \mu \mathrm{g}$ Hoechst $33342 \mathrm{dye} \mathrm{ml}^{-1}$, and mounted on slides. Microscopy was performed at $\times 200-$ $\times 400$ magnification with a fluorescence microscope equipped with a Leitz filter block A2.

\section{Preparation of spermatozoa}

The spermatozoa were obtained from the cauda epididymis by mincing the large diameter tubules in $0.9 \mathrm{ml}$ of warmed equilibrated Whitten Medium (WM; Whitten, 1971) supplemented with $3 \mathrm{mg}$ crystallized BSA $\mathrm{ml}^{-1}$ and overlaid with washed oil. After $10 \mathrm{~min}$, fragments were removed and the sperm suspension was capacitated by incubating for $2 \mathrm{~h}$ at $37^{\circ} \mathrm{C}$. Only suspensions showing excellent sperm motility, evaluated by phase-contrast microscopy, were used for insemination at a final concentration of $5 \times 10^{4}$ spermatozoa $\mathrm{ml}^{-1}$.

\section{Sperm-egg fusion assay}

Zonae pellucidae were dissolved by treating the oocytes briefly in acidic Tyrode's solution, pH 2.5 (Nicolson et al., 1975). These zona-free oocytes were cultured for $15 \mathrm{~min}$ in WM containing $0.1 \mu \mathrm{g}$ DNA-staining Hoechst 33342 dye $\mathrm{ml}^{-1}$ (Conover and Gwatkin, 1988; Tatone et al., 1994), extensively washed and then incubated in fertilization drops for $15,30,45$ and $60 \mathrm{~min}$ at $37^{\circ} \mathrm{C}$ in $5 \% \mathrm{CO}_{2}$ in air. At the end of the co-incubation period, eggs were washed in WM to remove spermatozoa loosely associated with the oocyte surface, fixed 
for $30 \mathrm{~min}$ at room temperature in $3.7 \%(\mathrm{w} / \mathrm{v})$ paraformaldehyde and mounted on slides. Spermatozoa were considered fused when the heads associated with the oolemma exhibited fluorescent DNA (Hinkey et al., 1986; Zuccotti et al., 1995).

\section{In vitro Fertilization}

On the basis of the results of the fusion experiments, oocytes were inseminated for $60 \mathrm{~min}$, washed to remove excess adherent spermatozoa and cultured in $W M$ at $37^{\circ} \mathrm{C}$ in $5 \% \mathrm{CO}_{2}$ in air for $6 \mathrm{~h}$. At this time, the eggs were examined for the presence of male and female pronuclei, and those without clearly visible pronuclei were loaded with $5 \mu \mathrm{g}$ Hoechst 33342 dye $\mathrm{ml}^{-1}$ and further analysed for their chromatin configurations by the fluorescence microscopy.

In the fertilization conditions used, polyspermy seldom occurred, and its degree was limited to the presence of two-three spermatozoa within an oocyte.

\section{Statistical analyses}

Experiments were repeated five times, and a minimum of 100 oocytes were analysed. The effect of replicates was examined by analysis of variance using arcsin transformation of proportions. Since the analysis did not show replicate effects, data were pooled and expressed as percentages. Statistical significance was analysed using the chi-square test with Yate's correction for homogeneous proportions (Fleiss, 1981). Experimental groups were compared pairwise according to the Scheffe procedure (Wolson, 1987). Significant differences were defined by a $P$ value of less than 0.05 .

\section{Results}

\section{In vitro maturation}

After culture for $17 \mathrm{~h}, 82 \%$ of the denuded oocytes, derived from early antral follicles had undergone germinal vesicle breakdown (GVBD) compared with $95 \%$ of oocytes derived from preovulatory follicles matured cumulus-intact or cumulusfree $(P>0.01)$. As evidenced by extrusion of the polar body, $95 \%$ of cumulus-intact, $50 \%$ of cumulus-free and $39 \%$ of denuded oocytes matured to metaphase II (cumulus-intact versus cumulus-free or denuded: $P<0.001$; cumulus-free versus denuded: $P>0.01$; Fig. 1). Cytological examination of oocytes stained with Hoechst 33342 dye revealed that all the maturing oocytes without a polar body were arrested at metaphase I (Fig. 2). The addition of preantral granulosa, early antral or cumulus cells to the maturation medium had no significant effect on the transition from metaphase I to metaphase II of the denuded or cumulus-free oocytes cultured in vitro (data not shown). In subsequent experiments, only oocytes extruding the first polar body were used.

The ability of early antral and preovulatory oocytes to fuse with spermatozoa after in vitro maturation under different culture conditions

Early antral and preovulatory oocytes preloaded with Hoechst 33342 dye were inseminated for increasing periods

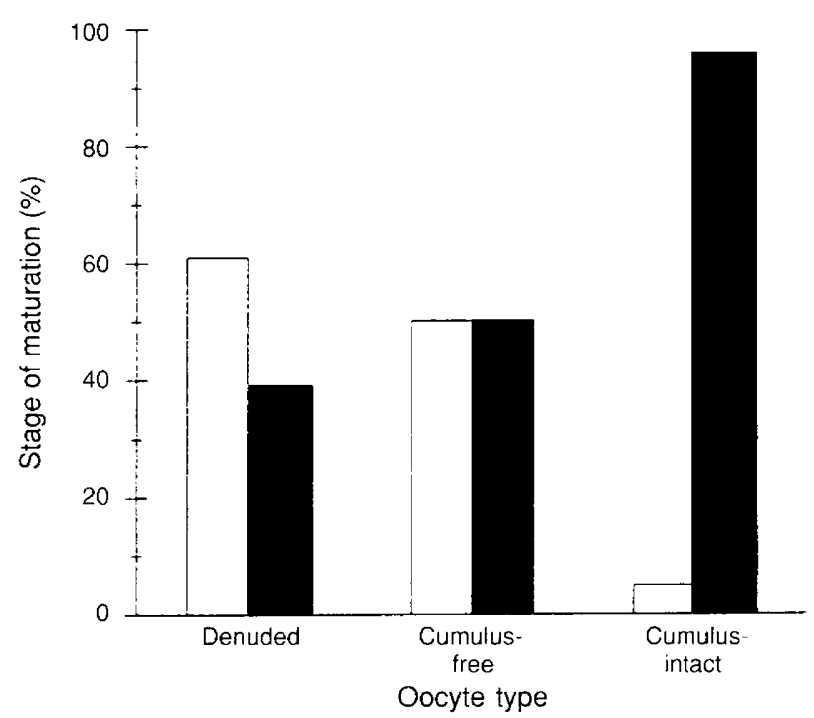

Fig. 1. Maturation competence of mouse oocytes derived from early antral (denuded oocytes) and from preovulatory follicles matured cumulus-intact or cumulus-free. All the oocytes were matured in vitro for 17 h. ( $\square$ ) Oocytes at metaphase I; ( $\mathbf{a}$ ) oocytes at metaphase II.

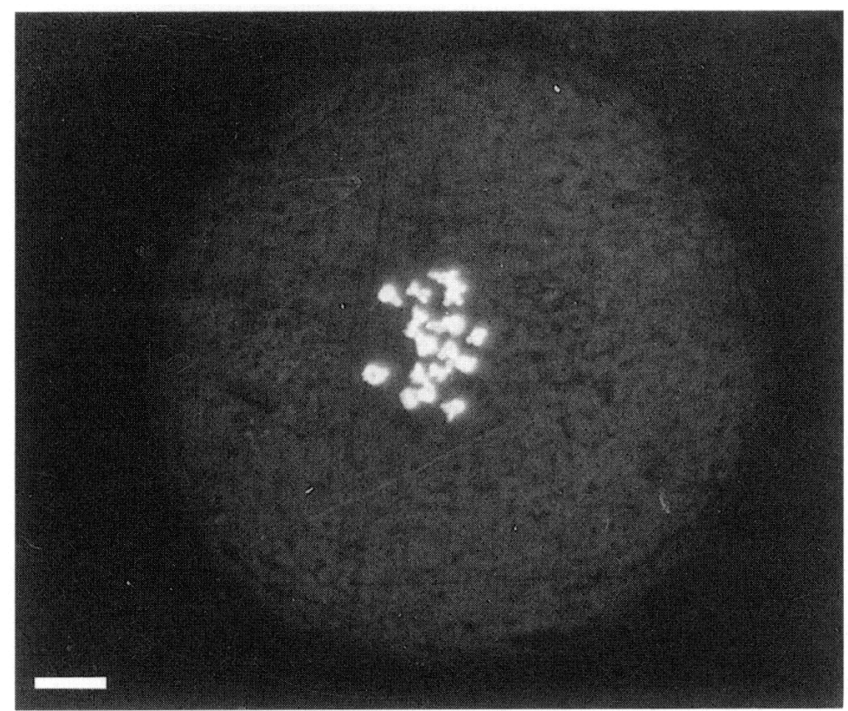

Fig. 2. Representative photomicrograph of a cumulus-free mouse oocyte without a polar body after $17 \mathrm{~h}$ of culture. The oocyte was

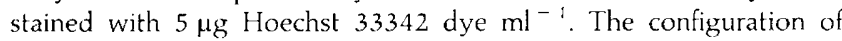
chromosomes is typical of metaphase I. Scale bar represents $10 \mu \mathrm{m}$.

and the presence of fused sperm heads assessed to investigate whether the ability of the oocyte plasma membrane to fuse with spermatozoa was affected by development of the antral follicle and by the maintenance of cumulus cell interactions during meiotic maturation. Preovulatory oocytes matured in vitro either as cumulus-intact or as cumulus-free exhibited similar percentages of sperm-fused eggs at all periods tested (Fig. 3). Maximum values of gamete fusion were reached when oocytes had been exposed to capacitated spermatozoa for $45 \mathrm{~min}$, at which time approximately $80 \%$ of the eggs showed at least one fluorescent sperm head. The time course of sperm-oocyte fusion of early antral oocytes (denuded oocytes) 


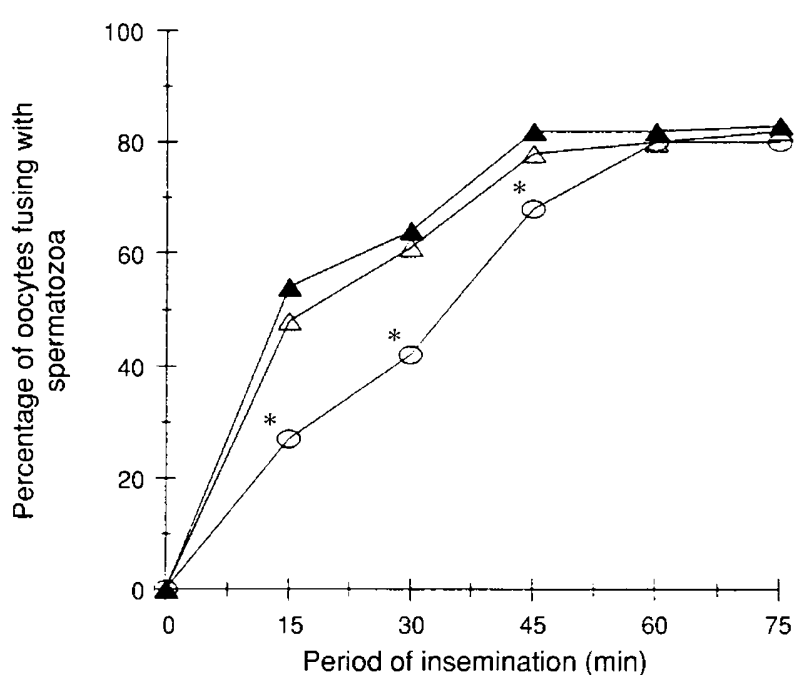

Fig. 3. The kinetics of sperm-oocyte fusion of mouse oocytes obtained from different classes of antral follicles. (O) Denuded oocytes from early antral follicles and matured in vitro devoid of companion granulosa cells; $(\boldsymbol{\Delta})$ cumulus-intact oocytes from preovulatory follicles and matured in vitro in association with cumulus cells; $(\triangle)$ cumulus-free oocytes from preovulatory follicles and matured in vitro without cumulus cells. Data are expressed as the percentage of inseminated oocytes with fluorescent sperm heads. *Values for denuded oocytes are significantly different from those of cumulusintact and cumulus-free oocytes.

was slower than that of preovulatory oocytes; the major difference was observed after 15 min of sperm-egg interaction, when only $30 \%$ of denuded oocytes exhibited fluorescent sperm heads compared with about $50 \%$ of cumulus-intact or cumulus-free oocytes $(P<0.01$; Fig. 3). Thirty minutes after insemination, sperm-oocyte fusion had occurred in $42 \%$ of denuded oocytes, whereas, at this time, the percentage of preovulatory oocytes with fused sperm heads was about $56 \%$ $(P<0.01)$. Forty-five minutes after insemination this difference was further reduced $(69 \%$ denuded oocytes versus about $80 \%$ preovulatory oocytes, $P<0.05$ ), and was completely eliminated $60 \mathrm{~min}$ after insemination, with $80 \%$ of denuded oocytes showing fused sperm heads (denuded versus preovulatory oocytes, $P>0.01$ ). The ability of denuded oocytes to fuse with spermatozoa was increased by maturation in media containing early antral granulosa cells or cumulus cells; under these conditions the kinetics of sperm-oocyte fusion followed that of preovulatory oocytes (Fig. 4). In contrast, the ability of denuded oocytes to fuse with spermatozoa was not improved by the presence of preantral granulosa cells during meiotic progression. Early antral granulosa cells were divided into two groups, one group was treated as described earlier for preantral granulosa cells and the other group acted as controls to evaluate whether this inability was due to the enzymatic procedures used for obtaining preantral granulosa cells. Denuded oocytes were then matured in vitro in the presence of one of the two groups of somatic cells, and their fusion capacity evaluated as described above. At any of the times tested (15-45 $\mathrm{min}$ ) the ability of denuded oocytes to fuse with spermatozoa was comparable with that of preovulatory oocytes, regardless of the enzymatic treatment of early antral granulosa cells (data not shown).

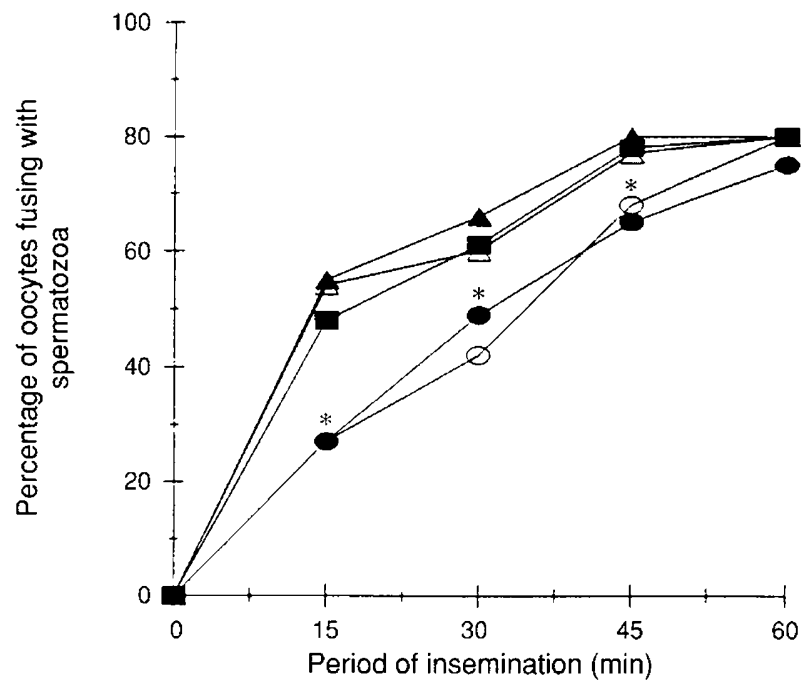

Fig. 4. The kinetics of sperm-oocyte fusion of mouse oocytes from early antral follicles (denuded oocytes) matured either in $(O)$ culture medium or in the presence of $(-)$ preantral granulosa, $(\triangle)$ early antral and $(\boldsymbol{\Delta})$ cumulus cells were compared to those of $(\boldsymbol{Q})$ cumulus free oocytes matured in culture medium. Different insemination periods were used. Data are expressed as the percentage of inseminated oocytes with fluorescent sperm heads. *Values for denuded oocytes are significantly different from those of cumulus-free oocytes.

The ability of early antral and preovulatory oocytes to form a male pronucleus after in vitro maturation under different culture conditions

The capacity of early antral and preovulatory oocytes to support normal fertilization was evaluated by inseminating denuded oocytes derived from early antral follicles, cumulusfree and cumulus-intact oocytes derived from preovulatory follicles, for $60 \mathrm{~min}$ and examining them $6 \mathrm{~h}$ later for formation of pronuclei. Although for the selected insemination period the three classes of oocyte showed equivalent percentages of sperm fused eggs (Fig. 3), their abilities to form male pronuclei were quite different. In particular, only $39 \%$ of denuded oocytes formed a male pronucleus compared with $50 \%$ of cumulus-free oocytes $(P<0.01)$ and $73 \%$ of cumulus-intact oocytes (denuded versus cumulus-intact oocytes, $P<0.001$; cumulus-free versus cumulus-intact oocytes, $P<0.01$ ) (Table 1 ). The remaining inseminated oocytes were characterized by the presence of partially decondensed fluorescent sperm heads, and most of the eggs were arrested at metaphase II (Fig. 5).

It was evaluated whether the fertilizability of the oocytes matured without companion somatic cells could be affected by secretory factors released during in vitro maturation by preantral, early antral granulosa or cumulus cells. The results of these experiments showed that the presence of cumulus cells during meiotic maturation significantly improved the percentages of denuded and cumulus-free oocytes undergoing fertilization when compared with their counterparts matured in culture medium. The proportion of denuded oocytes with male pronuclei increased from $39 \%$ to $52 \%(P<0.01$; Table 2$)$, and that of cumulus-free oocytes from $50 \%$ to $61 \%(P<0.01$; Table 3). However, under these maturation conditions neither denuded nor cumulus-free oocytes formed male pronuclei at 
Table 1. Effect of antral follicle development and of cumulus cells on the ability of mouse oocytes to form a male pronucleus

\begin{tabular}{lccc}
\hline $\begin{array}{l}\text { Oocyte } \\
\text { class }\end{array}$ & $\begin{array}{c}\text { Total number } \\
\text { of eggs } \\
\text { inseminated }\end{array}$ & $\begin{array}{c}\text { Number of eggs with } \\
\text { partially decondensed } \\
\text { sperm heads } \\
(\%)\end{array}$ & $\begin{array}{c}\text { Number of eggs with } \\
\text { male pronucleus } \\
(\%)\end{array}$ \\
\hline $\begin{array}{l}\text { Denuded } \\
\text { Cumulus-free }\end{array}$ & 397 & $163(41)^{\mathrm{a}}$ & $155(39)^{\mathrm{a}}$ \\
Cumulus-intact & 376 & $113(30)^{\mathrm{b}}$ & $188(50)^{\mathrm{b}}$ \\
& 390 & $39(10)^{\mathrm{c}}$ & $285(73)^{\mathrm{c}}$
\end{tabular}

.1. Within each column, values with different superscripts are significantly different $(P<0.01)$.

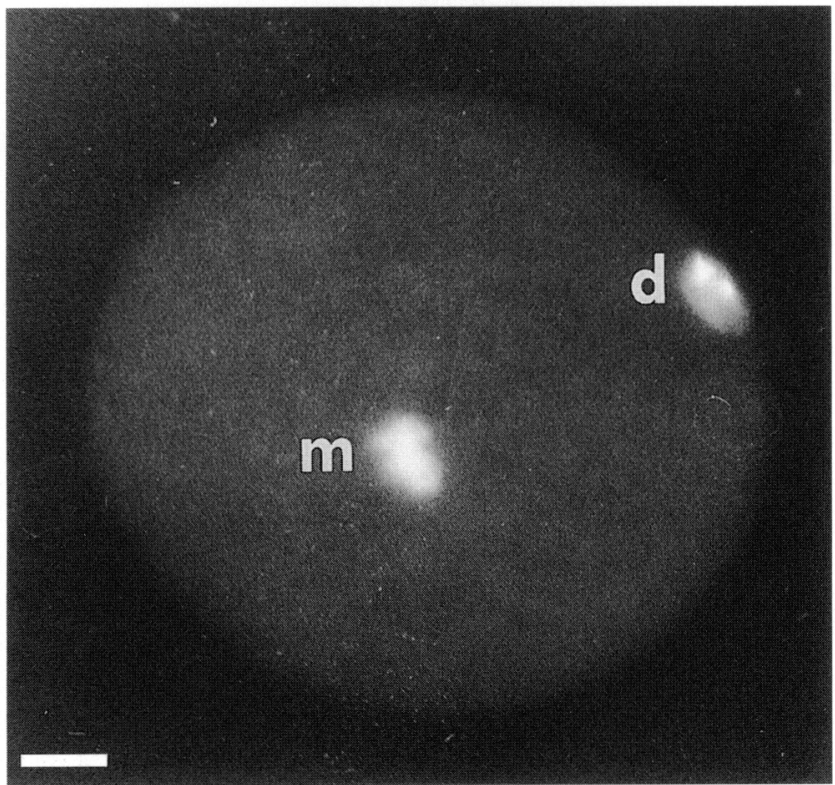

Fig. 5. Representative fluorescence micrograph of a cumulus-free mouse oocyte not showing a male pronucleus $6 \mathrm{~h}$ after fertilization in vitro. The oocyte was loaded with $5 \mu \mathrm{g}$ Hoechst $33342 \mathrm{dye} \mathrm{ml}^{-1}$. No male pronucleus is present. $\mathrm{d}$ : partially decondensed sperm head; $\mathrm{m}$ : chromosomes at metaphase II. Scale bar represents $10 \mu \mathrm{m}$.

proportions equivalent to those for cumulus-intact oocytes (see Tables $1-3$ ).

\section{Discussion}

In the present study the ability of mouse oocytes to direct and support the events of fertilization (taken here as sperm fusion/ penetration and formation of a male pronucleus) was shown to require the complete development of the antral follicle and the presence of cumulus cells during meiotic progression. Furthermore, our results on spontaneous meiotic maturation of mouse oocytes matured in vitro under various conditions confirm previous reports demonstrating that the maintenance of the physiological interactions between oocytes and surrounding cumulus cells significantly improves the ability of oocytes to override metaphase I arrest and to reach metaphase II (humans: Kennedy and Donahue, 1969; rabbits and cows: Robertson and
Baker, 1969; mice: Cross and Brinster, 1970; rats: Vanderhyden and Armstrong, 1989). In addition, maturation media conditioned by preantral, early antral granulosa and cumulus cells do not significantly increase the proportions of denuded or cumulus-free oocytes reaching metaphase II.

Fertilization in mammals is characterized by several steps, including initial contact between the oocyte and sperm surfaces, fusion of the two plasma membranes, incorporation of sperm heads, chromatin decondensation and pronuclei formation. The occurrence of all these biological events is essential for normal fertilization and requires a maturity of both oocyte plasma membrane and cytoplasm (Niwa ef al., 1976; Moor and Trounson, 1977; Thibault, 1977; Shalgi et al., 1979; Leibfried and Bavister, 1983; Schroeder and Eppig, 1984; LeibfriedRutledge et al., 1987; Mattioli et al., 1988a, b; Vanderhyden and Armstrong, 1989; Myles, 1993). The finding that oocytes derived from early antral follicles (denuded oocytes) show a slower kinetics of fusion compared with preovulatory oocytes indicates that, in mice, the acquisition of the properties of the oolemma specifically involved in sperm-oocyte fusion occurs concurrent with the development of the antral follicle. On the basis of these results, it can be inferred that one or more fusion molecules (Kellom et al., 1992; Tarone et al., 1993; Myles et al., 1994) may be present, but inactive (Green, 1993), or not homogeneously distributed (Tarone et al., 1993) over the oolemma of denuded oocytes. Moreover, because the site of sperm-egg fusion is generally considered as the area containing microvilli and cortical granules (Talansky ef al., 1991; Green, 1993), it is possible that the oolemma of denuded oocytes is characterized by a different arrangement of the microvilli compared with preovulatory oocytes, which may account for the delay in the sperm-oocyte fusion process observed in this class of germ cells. The fact that the kinetics of fusion of denuded oocytes can be improved to equate with that of preovulatory oocytes only by the addition of early antral granulosa or cumulus cells to the maturation medium indicates that this positive effect is due to the action of a secretory product(s) specifically generated by these follicular cells. Moreover, since cumulus-free and cumulus-intact preovulatory oocytes showed similar kinetics of sperm-egg fusion, it is possible to conclude that this ability is not influenced by the maintenance of direct cumulus cell-oocyte contacts during meiotic progression. In pigs, the presence of cumulus cells during meiotic progression is required to allow efficient penetration of the oocytes (Mattioli et al., 1988a, b; Galeati et al., 
Table 2. Effect of different types of follicular cells on the ability of denuded mouse oocytes derived from early antral follicles to form a male pronucleus

\begin{tabular}{lccc}
\hline $\begin{array}{l}\text { Maturation } \\
\text { conditions* }\end{array}$ & $\begin{array}{c}\text { Total number } \\
\text { of eggs } \\
\text { inseminated }\end{array}$ & $\begin{array}{c}\text { Number of eggs with } \\
\text { partially decondensed } \\
\text { sperm heads } \\
(\%)\end{array}$ & $\begin{array}{c}\text { Number of eggs with } \\
\text { male pronucleus } \\
(\%)\end{array}$ \\
\hline $\begin{array}{l}\text { Culture medium } \\
\text { Cumulus cells }\end{array}$ & 397 & $163(41)^{\mathrm{a}}$ & $155(39)^{\mathrm{a}}$ \\
Early antral granulosa cells & 306 & $92(30)^{\mathrm{b}}$ & $158(52)^{\mathrm{b}}$ \\
Preantral granulosa cells & 200 & $100(50)^{\mathrm{a}}$ & $67(34)^{\mathrm{a}}$ \\
& 205 & $92(45)^{\mathrm{a}}$ & $72(35)^{\mathrm{a}}$ \\
\hline
\end{tabular}

*The different follicular cell types were added to the culture medium just before oocyte maturation.

a.b Within each column, values with different superscripts are significantly different $(P<0.01)$.

Table 3. Effect of different types of follicular cell on the ability of cumulus-free mouse oocytes to form a male pronucleus

\begin{tabular}{lccc}
\hline $\begin{array}{l}\text { Maturation } \\
\text { conditions* }\end{array}$ & $\begin{array}{c}\text { Total number } \\
\text { of eggs } \\
\text { inseminated }\end{array}$ & $\begin{array}{c}\text { Number of eggs with } \\
\text { partially decondensed } \\
\text { sperm heads } \\
(\%)\end{array}$ & $\begin{array}{c}\text { Number of eggs with } \\
\text { male pronucleus } \\
(\%)\end{array}$ \\
\hline $\begin{array}{l}\text { Culture medium } \\
\text { Cumulus cells }\end{array}$ & 376 & $113(30)^{\mathrm{a}}$ & $188(50)^{\mathrm{a}}$ \\
Early antral granulosa cells & 297 & $66(22)^{\mathrm{b}}$ & $180(61)^{\mathrm{b}}$ \\
Preantral granulosa cells & 190 & $63(33)^{\mathrm{a}}$ & $95(50)^{\mathrm{a}}$ \\
& 203 & $64(31)^{\mathrm{a}}$ & $100(49)^{\mathrm{a}}$ \\
\hline
\end{tabular}

* The different types of follicular cells were added to the culture medium just before oocyte maturation.

${ }^{a, b}$ Within each column, values with different superscripts are significantly different $(P<0.01)$.

1991). Thus in mammals, the somatic compartment of antral follicles appears to play a critical role in the attainment of the terminal differentiation of the oolemma required for a successful sperm-egg interaction at fertilization.

The ability to progressively transform a sperm nucleus into a pronucleus (Usui and Yanagimachi, 1976; Borsuk, 1991) requires cytoplasmic maturation of the oocyte (Thibault, 1977; Yanagimachi, 1994), which results from the occurrence of stage-specific and coordinated responses, such as the maturation-associated changes in protein synthesis (Schultz and Wassarman, 1977; Eppig et al., 1994; McConnell et al., 1995) and the acquisition of the ability to release cortical granules (Ducibella ef al., 1990, 1993). The results reported here demonstrate that the acquisition of oocyte cytoplasmic maturation, as manifested by pronuclear formation, depends on completion of antral follicle development and on maintenance, during meiotic maturation, of efficient cell-to-cell communications between the oocyte and cumulus cells. This means that cumulus cells can significantly improve the process of cytoplasmic maturation, exerting other beneficial effects on the oocyte in addition to the positive influence on nuclear maturation (Cross and Brinster, 1970; present results) and to the maintenance of the penetrability of the zona pellucida (Schroeder and Eppig, 1984). Moreover, our results confirm that oocytes competent of completing nuclear maturation, but deficient in some critical factors essential for cytoplasmic maturation, fail to undergo normal fertilization (Kubiak, 1989).
This failure is demonstrated in our experiments by the high proportion of denuded and cumulus-free oocytes which, although penetrated, do not form a male pronucleus, indicating that these germ cells cannot undergo the cytoplasmic modifications necessary for normal fertilization. The fact that $39 \%$ of the inseminated denuded oocytes can form a normal male pronucleus suggests that early antral granulosa cells generate at least some regulatory factors sufficient to promote, in a limited number of more developed oocytes, the process of cytoplasmic maturation. Only when granulosa cells differentiate into cumulus cells is the production of a factor(s) that can induce, in almost all the oocytes, the terminal ooplasmic differentiation, activated. Among these still unknown regulative factors, some are probably released into the external medium, since the proportion of denuded and cumulus-free oocytes forming normal pronuclei is significantly increased by the presence of cumulus cells and of their products during the maturation period. Nevertheless, the observation that these matured oocytes never reach a fertilization rate equivalent to that of cumulus-intact oocytes indicates that other regulatory factors may be transferred to the oocyte only through gap junctions. The production of a variety of signal(s) during the preovulatory phase of maturation, which cooperate in the completion of ooplasmic maturation, may allow more efficient qualitative or quantitative control of oocytes capable of fertilization.

The study reported here did not investigate which aspect of cytoplasmic maturation may be lacking in the oocytes unable 
to transform a sperm nucleus into a normal male pronucleus. However, we hypothesize that during the transition of the antral follicle from the early to the preovulatory stage, oocytes at the germinal vesicle stage progressively acquire a number of properties that play an essential role in activating the process of normal cytoplasmic maturation. For instance, during meiotic maturation, mammalian oocytes significantly increase their cytoplasmic calcium stores (Tombes et al., 1992), an event considered an essential prerequisite for normal fertilization (Carroll et al., 1994). At fertilization, penetration by the spermatozoon induces the calcium transients necessary to trigger all the events of oocyte activation (Cuthbertson et al., 1981; Cuthbertson and Cobbold, 1985; Homa et al., 1993; Carroll et al., 1994). Thus, it is possible that the oocytes that are incapable of forming pronuclei may be characterized by defects in cytoplasmic maturation that prevent the complete development of the calcium stores or the inactivation of maturationpromoting factor (MPF) activity, necessary for the formation of female and male pronuclei (Meyerhof and Masui, 1977; Lorca et al., 1993; Yanagimachi, 1994).

In conclusion, competence of mouse oocytes to support normal fertilization is acquired in a stepwise manner, with the ability of the oolemma to fuse with spermatozoa developing before the acquisition of full ooplasm competence to transform sperm nuclei into male pronuclei. The present observations support previous results showing that the mouse oocyte sequentially acquires the competence to undergo nuclear (Sorensen and Wassarman, 1976; Szybek, 1972) and cytoplasmic maturation (Eppig and Schroeder, 1989; Eppig et al., 1994), as well as the capacity to develop from the two-cell to the blastocyst stage (Eppig and Schroeder, 1989). The ability of the factor(s), secreted by cumulus cells, to induce terminal differentiation in oocytes derived from early antral or preovulatory follicles and matured without companion somatic cells in vitro, may be useful for increasing the number of mammalian oocytes suitable for in vitro fertilization. An important basic question remains to be answered, that concerning the potential embryonic development of these oocytes, since the acquisition of the competence to support pronuclei formation does not assure development beyond this stage.

The authors wish to thank C. Tatone, M. Mattioli, R. Talevi and A. Mackay for critical reading of the manuscript, M. Valenti for statistical analysis, and G. Rossi for excellent technical assistance. This research was supported by grants from MURST (to S. Cecconi and R. Colonna) and from CNR (to R. Colonna).

\section{References}

Borsuk E (1991) Anucleate fragments of parthenogenetic eggs and of maturing oocytes contain complementary factors required for development of a male pronucleus Molecular Reproduction and Development 29 150-156

Carroll J, Swann K, Whittingham D and Whitaker M (1994) Spatiotemporal dynamics of intracellular $\left.{ }^{1} \mathrm{Ca}^{2+}\right\}$; oscillations during the growth and meiotic maturation of mouse oocytes Development 120 3507-3517

Conover JC and Gwatkin RBL (1988) Pre-loading of mouse oocytes with DNA-specific fluorochrome (Hoechst 33342) permits rapid detection of sperm-oocyte fusion Journal of Reproduction and Fertility 82 681-690

Cross PC and Brinster RL (1970) In vitro development of mouse oocytes Biology of Reproduction 3 298-307
Curci A, Bevilacqua A, Fiorenza MT and Mangia F (1991) Developmental regulation of heat-shock response in mouse oogenesis: identification of differentially responsive oocyte classes during Graafian follicle development Developmental Biology 144 362-368

Cuthbertson KSR and Cobbold PH (1985) Phorbol ester and sperm activate mouse oocytes by inducing sustained oscillations in cell $\mathrm{Ca}^{2+}$ Nature 316 $541-542$

Cuthbertson KSR, Whittingham DG and Cobbold PH (1981) Free $\mathrm{Ca}^{2+}$ increases in exponential phases during mouse oocyte activation Nature 294 $754-757$

Ducibella T, Duffy P, Reindollar R and Su B (1990) Changes in the distribution of mouse oocyte cortical granules and ability to undergo the cortical reaction during gonadotropin-stimulated meiotic maturation and aging in vivo Biology of Reproduction 43 870-876

Ducibella T, Kurasawa S, Duffy P, Kopf GS and Schultz RM (1993) Regulation of the polyspermy block in the mouse egg: maturation-dependent differences in cortical granule exocytosis and zona pellucida modifications induced by inositol 1,4,5-triphosphate and an activator of protein kinase-C Biology of Reproduction 48 1251-1257

Eppig JJ and Schroeder AC (1989) Capacity of mouse oocytes from preantral follicles to undergo embryogenesis and development to live young after growth, maturation and fertilization in vitro Biology of Reproduction $\mathbf{4 1}$ 268-276

Eppig JJ. Schultz RM, O'Brien M and Chesnel F (1994) Relationship between the developmental programs controlling nuclear and cytoplasmic maturation of mouse oocytes Developmental Biology 164 1-9

Fleiss JL (1981) Statistical methods for rates and proportions pp 87-88. Wiley, New York

Galeati G, Modina S, Lauria A and Mattioli M (1991) Follicle somatic cells influence pig oocyte penetrability and cortical granule distribution Molecular Reproduction and Development 29 40-46

Green DPL (1993) Mammalian fertilization as a biological machine: a working model for adhesion and fusion of sperm and oocyte Human Reproduction $\mathbf{8}$ 91-96

Hinkey RE, Wright DB and Lynn JW (1986) Rapid visual detection of spermegg fusion using the DNA-specific fluorochrome Hoechst 33342 Developmental Biology 118 148-154

Homa ST, Carroll J and Swan K (1993) The role of calcium in mammalian oocyte maturation and egg activation Human Reproduction 8 1274-1281

Kellom T, Vick A and Boldt $\mathbf{J}$ (1992) Recovery of penetration ability in protease-treated zona-free eggs occurs coincident with recovery of a cell surface $94 \mathrm{kD}$ protein Molecular Reproduction and Development 33 46-52

Kennedy JF and Donahue RP (1969) Human oocytes: maturation in chemically defined media Science $164 \quad 1292-1293$

Kubiak JZ (1989) Mouse oocytes gradually develop the capacity for activation during the metaphase II arrest Developmental Biology 136 537-545

Leibfried ML and Bavister BD (1983) Fertilizability of in vitro matured oocytes from golden hamsters Journal of Experimental Zoology 226 481-485

Leibfried-Rutledge ML, Critser ES, Eyestone WH, Northey DL and First NL (1987) Development potential of bovine oocytes matured in vitro or in vivo Biology of Reproduction 36 376-383

Lorca T, Cruzalegui FH, Fesquet D, Cavadore JC, Mery J, Means A and Doree M (1993) Calmodulin-dependent protein kinase II mediates inactivation of MPF and CSF upon fertilization of Xenopus eggs Nature $366 \quad 270-273$

McConnell JML, Campbell L and Vincent C (1995) Capacity of mouse oocytes to become activated depends on completion of cytoplasmic but not nuclear meiotic maturation Zygote 3 45-55

Mattioli M, Galeati G and Seren E (1988a) Effect of follicle somatic cells during pig ocyte maturation on egg penetrability and male pronucleus formation Gamete Research 20 177-183

Mattioli M, Galeati G, Bacci ML and Seren E (1988b) Follicular factors influence oocyte fertilizability by modulating the intercellular cooperation between cumulus cells and oocyte Gamete Research $21223-232$

Meyerhof PG and Masui Y (1977) $\mathrm{Ca}^{2+}$ and $\mathrm{Mg}^{2+}$ control of cytostatic factors from Rana pipiens oocytes which cause metaphase and cleavage arrest Developmental Biology $61214-229$

Moor RM and Trounson AO (1977) Hormonal and follicular factors affecting maturation of sheep oocytes in vitro and their subsequent developmental capacity Journal of Reproduction and Fertility 49 101-109

Myles DG (1993) Molecular mechanisms of sperm-egg membrane binding and fusion in mammals Developmental Biology 158 35-45 
Myles DG, Kimmel LH, Blobel CP, White JM and Primakoff P (1994) Identification of a binding site in the disintegrin domain of fertilin required for sperm-egg fusion Proceedings of the National Academy of Sciences USA 91 $4195-4198$

Nicolson GL, Yanagimachi R and Yanagimachi H (1975) Ultrastructural localization of lectin-binding sites on the zonae pellucidae and plasma membranes of mammalian eggs Journal of Cell Biology 66 263-274

Niwa K, Miyake M, Iritani A and Nishikawa Y (1976) Fertilization of rat oocytes cultured in vitro from various stages of maturation Journal of Reproduction and Fertility 47 105-106

Pedersen T and Peters H (1968) Proposal for classification of oocytes and follicles in the mouse ovary Journal of Reproduction and Fertility 17 555557

Robertson JE and Baker RD (1969) Role of female sex steroids as possible regulators of oocyte maturation. Second Annual Meeting of The Society for the Study of Reproduction, California, Abstract 57

Schroeder AC and Eppig JJ (1984) The developmental capacity of mouse oocytes that matured spontaneously in vitro is normal Developmental Biology 102 493-497

Schultz RM and Wassarman PM (1977) Specific changes in the pattern of protein synthesis during meiotic maturation of mammalian oocytes in vitro Proceedings of the National Academy of Sciences USA 74 538-541

Shalgi R, Dekel N and Kraicer PF (1979) The effect of LH on the fertilizability and developmental capacity of rat oocytes matured in vitro Joumal of Reproduction and Fertility 55 429-435

Sorensen RA and Wassarman PM (1976) Relationship between growth and meiotic maturation of mouse oocytes Developmental Biology 50 531-536

Staigmiller RB and Moor RM (1984) Effect of follicle cells on the maturation and developmental competence of ovine oocytes matured outside the follicle Gamete Research 9 221-229

Szybek K (1972) In vitro maturation of oocytes from sexually immature mice Journal of Endocrinology 54 527-528

Talansky BE, Malter HE and Choen J (1991) A preferential site for sperm-egg fusion in mammals Molecular Reproduction and Development 28 183188
Tarone G, Russo MA, Hirsch E, Odorisio T, Altruda F, Silengo L and Siracusa G (1993) Expression of $\beta 1$ integrin complexes on the surface of unfertilized mouse oocyte Development 117 1369-1375

Tatone C, van Eekelen CG and Colonna R (1994) Plasma membrane block to sperm entry occurs in mouse eggs upon parthenogenetic activation Molecular Reproduction and Development 38 200-208

Thibault C (1977) Are follicular maturation and oocyte maturation independent processes? Journal of Reproduction and Fertility 51 397-411

Tombes RM, Simerly C, Borisy GG and Schatten G (1992) Meiosis, egg activation, and nuclear envelope breakdown are differentially reliant on $\mathrm{Ca}^{2+}$, whereas germinal vesicle breakdown is $\mathrm{Ca}^{2+}$ independent in the mouse oocyte Journal of Cell Biology 117 799-811

Usui N and Yanagimachi R (1976) Behaviour of hamster sperm nuclei incorporated into eggs at various stages of maturation, fertilization and early development. The appearance and disappearance of factors involved in sperm chromatin decondensation in egg cytoplasm Journal of Ultrastructural Research 57 276-288

Vanderhyden BC and Armstrong DT (1989) Role of cumulus cells and serum on the in vitro maturation, fertilization and subsequent development of rat oocytes Biology of Reproduction 40 720-728

van de Sandt JJM, Schroeder AC and Eppig JJ (1990) Culture media for mouse oocyte maturation affect subsequent embryonic development Molecular Reproduction and Development 25 164-171

Whitten WK (1971) Nutrient requirements for culture of preimplantation embryos in vitro Advances in the Biosciences 6 129-139

Whittingham DG (1971) Culture of mouse ova Journal of Reproduction and Fertility $147-21$

Wolson RF (1987) Statistical methods for the Analysis of Biomedical Data pp 221-250. Wiley, New York

Yanagimachi R (1994) Mammalian fertilization. In The Physiology of Reproduction 2nd edn pp 189-317 Eds E Knobil and JD Neill. Raven Press Ltd, New York

Zuccotti M, Piccinelli A, Rossi PG, Garagna S and Redi CA (1995) Chromatin organization during mouse oocyte growth Molecular Reproduction and Development 41 479-485 